\title{
TBRs, a methodology for the multi-scalar cartographic analysis of the distribution of plant formations
}

TRB, una metodología para el análisis cartográfico multiescalar de la distribución de formaciones vegetales

\section{Rafael Cámara Artigas}

rcamara@us.es

Departamento de Geografía Física y Análisis Geográfico Regional

Universidad de Sevilla (España)

\section{Fernando Díaz del Olmo}

delolmo@us.es

Departamento de Geografía Física y Análisis Geográfico Regional

Universidad de Sevilla (España)

José Ramón Martínez Batlle

joseramon@geografiafisica.org

Departamento de Geografía

Universidad Autónoma de Santo Domingo (República Dominicana) 


\begin{abstract}
An analytical and cartographic method of biomass distribution and plant formations at a multiscalar level is developed based on bioclimatic variables extracted from the Thornthwaite Water Balance (WB) and the Bioclimatic Balances (BB) of Montero de Burgos \& González Rebollar. As a result, a distribution map involving Types of Bioclimatic Regimens (TBR) is obtained leading to the identification of a multi-scale classification at different levels: zonal (macro-scale) with 5 types, regional (meso-scale) with 27 types, and local (micro-scale) with 162 plant formations subtypes, conditioned by lithology-soils, the relief exposure to wind or sunstroke respectively and obtained through the combination of TBR and ombroclimates.
\end{abstract}

Key words: Types of Bioclimatic Regimens (TBR); Bioclimatic Balances (BB); Thornthwaite Water Balance (WB); ombroclimates; continuous surface databases.

\title{
Resumen
}

Se desarrolla un método analítico y cartográfico de distribución de biomasa y formaciones de plantas a nivel multiescalar basado en variables bioclimáticas extraídas del Balance hídrico de Thornthwaite (WB) y las Balanzas bioclimáticas (BB) de Montero de Burgos y González Rebollar. Como resultado, se obtiene un mapa de distribución que da lugar a los Tipos de Regímenes Bioclimáticos (TRB) y que conduce a la identificación de una clasificación multiescalar en diferentes niveles: zonal (macroescala) con 5 tipos, regional (mesoescala) con 27 tipos, y local (microescala) con 162 subtipos de formaciones vegetales condicionadas por suelos litológicos, la exposición al viento o insolación, y obtenida mediante la combinación de TBR y ombroclimas.

Palabras clave: tipos de regímenes bioclimáticos (TRB); Balance Bioclimático (BB); Balance Hídrico de Thornthwaite $(\mathrm{BH})$; ombroclimas; Bases de datos continuas de superficie.

\section{Introduction and objectives}

In order to introduce and justify the method set out below, let us outline the progress made in determining the limits of climatic variables in the distribution of plant formations, and their cartographic expression since the end of the 19th century to the present day. They can be grouped into four types depending on their purpose and classification elements: physiognomic, ecological, climatic and bioclimatic. 


\subsection{Physiognomic classifications}

At the end of the 19th century, the concept of plant formation had been introduced by Grisebach in 1838 and Kerner (1895) defined it as "the current expression of certain conditions of life, composed of associations that differ in their floristic composition, which coincides with the seasonal conditions and its biological forms". This concept, developed by O. Drude (1890), establishes five categories of plant formations based on their physiognomy.

Schimper's work (1903) is based on the climate-soil duality, distinguishing between climatic formations controlled by the climate and edaphic formations controlled by the soil, which form small enclaves within the large areas of the former formations. The work of Brockmann-Jerosch (1907) and Brockmann-Jerosch \& Rübel (1912) established an ecophysiognomic classification, in four overall groups:

- ligneous (with silva and fruticeta),

- herbaceous (aquiherbosa and terriherbosa),

- deserta and errantia.

This classification aims to show that climatic variables can lead to potential formations, resulting in a typology containing 29 classes of formations found on Earth.

Elhaï (1968) established a physiognomic classification based on the vertical and horizontal structure and phenology of plant formations. Based on this, and with the support the UNESCO, Ellenberg \& Mueller-Dombois (1967) created a physiognomic-structural classification. Its main aim was to provide a global classification and map of vegetation using a 1:1,000,000 scale, published by the UNESCO Committee in 1969 and 1973, and by Ellenberg \& Mueller-Dombois in 1974. Subsequently, Goldsmith (1974) compared this classification to that of Fosberg (1961). This is the one that has persisted in subsequent classifications. Briefly, it presents the following hierarchy that distinguishes between 225 different types:

- Formation class or overall type (7 classes similar to those of the Brockmann-Jerosch \& Rübel classification): silva, fruticeta, herbosa, deserta and aquatic plant formations.

- Subclass. The classes are subdivided based on phenology and the plants' water requirements (in aquatic plants).

- Group of formations is the range into which the subclasses are divided, taking into account climatic and geographic characteristics. 
- Formations are the basic range and are subdivided into subformations and variations of the formations based on morphological or environmental characteristics.

\subsection{Ecological classifications}

Based on Drude's physiognomic classification, Diels (1908) identified 18 plant formations on the Earth grouped by structure into four types: forests, shrubs, grasslands and pastures. This was sorted into four ecological groups: hydatophytia, mesophytia, hydrophytia and xerophytia), resulting in the first ecological classification of plant formations.

Warming's classification (1909) is based on the nomenclature proposed by Clements (1909). It is based on the moisture variable, establishing a classification of:

- soil with usable water (hidrophytos y helophytos),- physiologically dry soil (oxilophytos, psicrophytos, halophytos),

- physically dry soil (litophytos, psammophytos, quesophytos),

- dry climate (eremophyłos, psilophyllos, eclerophyllos),

- dry soil and favourable climate and soil (mesophytos).

In Spain, E. Huguet del Villar, brought together the currents existing until that time in biogeography, and transferred it in his Geobotánica (1929) into an ecological classification. In it he introduces the concept of sinecia: defined and individualised botanical cohabitation (a formation is a sinecia from the biotypical perspective, and he defines association as a taxonomic sinecia) (Table 1). The ecological titles based on Clements' work, incorporated internationally by Warming and in Spain by Huguet del Villar (1929), comprise the basis for the ecological titles that we have included in our typologies. 
Table 1. E. Huguet del Villar's ecological classification (1929)

\begin{tabular}{|c|c|c|c|}
\hline \multirow{9}{*}{ Oecophyta } & \multirow{2}{*}{$\begin{array}{l}\text { Hidrophytia } \\
\text { (aquatic environment) }\end{array}$} & \multicolumn{2}{|c|}{ Holohidrophytia } \\
\hline & & \multicolumn{2}{|l|}{ Helophytia } \\
\hline & \multirow{7}{*}{$\begin{array}{l}\text { Pezophytia } \\
\text { (surface environment) }\end{array}$} & \multirow{2}{*}{ Mesophytia } & Higrophytia \\
\hline & & & Tropophytia \\
\hline & & \multirow{2}{*}{$\begin{array}{l}\text { Xerophytia } \\
\text { scarce water }\end{array}$} & Mesophytia \\
\hline & & & Hyperxerophytia \\
\hline & & \multicolumn{2}{|c|}{$\begin{array}{l}\text { Psychrophytia } \\
\text { extreme temperature by default }\end{array}$} \\
\hline & & \multicolumn{2}{|c|}{$\begin{array}{l}\text { Halophytia } \\
\text { considering the basicity of the soil }\end{array}$} \\
\hline & & \multicolumn{2}{|c|}{$\begin{array}{l}\text { Oxiphytia } \\
\text { considering the acidity of the soil }\end{array}$} \\
\hline
\end{tabular}

Source: own elaboration

\subsection{Climatic classifications}

Thornthwaite $(1933,1948)$ carried out a classification of the Earth's climates and used four interlinked criteria at the same time:

a) the potential evapotranspiration (thermal efficacy) and its summer concentration,

b) the water vapour balance (ombrothermic index) and its seasonal humidity variation,

He established 9 overall types based on the ombrothermic index (Table 2) and 81 subtypes thermal efficiency ( 9 for each type of precipitation zone). It is really a climatic classification.

Köppen's classification $(1918,1936)$ is also climatic, given that it is based on strictly climatic parameters. It principally applies average monthly and annual precipitation and temperatures and matches them to climatic types with characteristic vegetation. Types are expressed with two or three letters, with 5 broad groups and 24 subtypes. The first letter determines the macroclimate based on temperatures, precipitation and latitude, and is designated using a capital letter (Table 3). The subtypes are indicated with lower-case letters. 
Table 2. Types based on the ombrothermic Thornthwaite's index

\begin{tabular}{|c|c|c|}
\hline $\begin{array}{c}\text { OMBROTHERMIC } \\
\text { TYPE (ITh) }\end{array}$ & DESCRIPTION & CRITERION \\
\hline$A$ & Perhumid & $I_{\text {Th }}>100$ \\
\hline$B_{4}$ & Very humid & $80<I_{\text {Th }} \leq 100$ \\
\hline$B_{3}$ & Highly humid & $60<I_{\text {Th }} \leq 80$ \\
\hline$B_{2}$ & Moderate humid & $40<I_{\text {Th }} \leq 60$ \\
\hline$B_{1}$ & Low humid & $20<I_{\text {Th }} \leq 40$ \\
\hline$C_{2}$ & Moist subhumid & $0<I_{\text {Th }} \leq 20$ \\
\hline$C_{1}$ & Dry subhumid & $-20<I_{\text {Th }} \leq 0$ \\
\hline$D$ & Semiarid & $-40<I_{\text {Th }} \leq-20$ \\
\hline$E$ & Arid & $-60<I_{\text {Th }} \leq-40$ \\
\hline
\end{tabular}

Source: own elaboration based in Thornthwaite (1948)

Table 3. Reference parameters for Köppen's classification.

Average monthly temperature ( $\mathrm{Tm})$; average temperature of the coldest month (Tf); average temperature of the warmest month (Tc)

\begin{tabular}{|c|c|c|c|}
\hline CLIMATE TYPE & CHARACTERISATION & TEMPERATURE & ANNUAL P \\
\hline A & Tropical/megathermal & Tm $>18^{\circ} \mathrm{C}$ & $>$ PET \\
\hline B & dry & Threshold $<$ PET \\
\hline C & Temperate/mesothermal & $\begin{array}{r}-3^{\circ} \mathrm{C}<\mathrm{Tf}<18^{\circ} \mathrm{C} \\
\mathrm{Tc}>10^{\circ} \mathrm{C}\end{array}$ & P $>$ PET \\
\hline D & Continental/mesothermal & $\begin{array}{r}\mathrm{Tf}<-3^{\circ} \mathrm{C} \\
\mathrm{Tc}>10^{\circ} \mathrm{C}\end{array}$ & P $>$ PET \\
\hline E & Cold/microthermal & $\mathrm{Tc}<10^{\circ} \mathrm{C}$ & \\
\hline
\end{tabular}

Source: own elaboration

In 1951, A. Miller published a new climatic classification of the Earth. Unlike in that of Köppen $(1918,1936)$, vegetation is the key factor. Vegetation is conditional on the rainfall regime, except in mountainous and polar areas where the temperature and (in certain circumstances) the soil are 
the determining factors. They take into account the following principles of an analytic and quantitative nature (Table 4):

a) the isotherm at $10^{\circ} \mathrm{C}$ in the warmest month is the thermal limit for forest formation.

b) the isohyet of $250 \mathrm{~mm} /$ year is the limit for the desert or the occasional steppe,

c) the isotherm at $6^{\circ} \mathrm{C}$ in the coldest month is the limit between the evergreen and deciduous forests, assuming the lack of a prolonged drought

d) the isoline for six months of average temperature below $6^{\circ} \mathrm{C}$ is the limit for leafy deciduous varieties.

Table 4. Miller's classification latitudinal groups. Average monthly temperature (Tm); average temperature of the warmest month (Tc)

\begin{tabular}{|c|c|c|c|}
\hline CLIMATE TYPE & CHARACTERISATION & TEMPERATURE & ANNUAL P \\
\hline$A$ & Hot climates & $\operatorname{Tm}>=18^{\circ} \mathrm{C}$ & \\
\hline B & $\begin{array}{l}\text { Temperate/hot } \\
\text { climates }\end{array}$ & $\mathrm{Tm}>=6^{\circ} \mathrm{C}$ & \\
\hline C & $\begin{array}{l}\text { Temperate/cold } \\
\text { climates }\end{array}$ & $\begin{array}{c}1 \text { to } 5 \text { months } \\
\mathrm{Tm}<6^{\circ} \mathrm{C}\end{array}$ & \\
\hline$D$ & Cold climates & $\begin{array}{c}\text { Over } 6 \text { months } \\
\operatorname{Tm}<6^{\circ} \mathrm{C}\end{array}$ & \\
\hline E & Polar climates & $\begin{array}{c}\mathrm{Tc}<10^{\circ} \mathrm{C} ; \\
\text { latitude }>65^{\circ}\end{array}$ & \\
\hline $\mathrm{F}$ & Desert climates & & $\mathrm{P}<250 \mathrm{~mm}$ \\
\hline
\end{tabular}

Source: own elaboration

Bagnouls \& Gaussen's classification (1957) was based on the interpretation of climatic diagrams (graphs showing precipitation and temperature) designed by Gaussen (1955). It was based on observing the thermal curve of the Gaussen diagram to find out whether it is in one of these five overall groups:

- hot climate

- temperate/hot climate

- temperate/cold climate 
- cold climate

- glacial climate

Subsequently, they observed the number of months with an average temperature above $\mathrm{O}^{\circ} \mathrm{C}$, and the number of months in which monthly precipitation is lower than or equal to double the temperature.

\subsection{Biolimatic classifications}

Holdridge's system (1947, expanded in 1967), classifies the various areas of the world based on Life Zones, a group of plant communities within a natural climate division. The factors considered to classify a region are the biotemperature (a range of temperatures between 0 and $30{ }^{\circ} \mathrm{C}$ ). It is a bioclimatic classification that defines 7 latitudinal regions and 8 humidity provinces, which result in 38 subtypes.

Walter, in turn, created a biome classification in 1977 based on the ombrothermic diagrams of the climatological atlas (Klimadiagram Weltatlas) that he had produced with Lieth in 1967. Based on a simple set of diagrams it describes the type of vegetation and the soils that correspond to each climate. This classification defines 10 types of bioclimates ( 9 zonal and 1 azonal, the mountain climate) as the result of the combination of 8 thermometric curves:

- Two types with the average temperature greater than $20{ }^{\circ} \mathrm{C}$ (Type 1 and 2).

- One type greater than $10^{\circ} \mathrm{C}$ (Type 3 ).

- One type lower than $20^{\circ} \mathrm{C}$ and greater than $0{ }^{\circ} \mathrm{C}$ (Type 4).

- Three types with a maximum lower than $10{ }^{\circ} \mathrm{C}$ and minimums lower than $0{ }^{\circ} \mathrm{C}$ (Types 5,6 and 7).

- One type with a maximum lower than $0^{\circ} \mathrm{C}$ (Type 8), azonal climate, the mountain climate. Type of bioclimate $X$.

And 2 typical rainfall curves:

- With a minimum, in summer or winter (Type a) in P curve.

- With two or more minimums for precipitation per year (Type b) in P curve.

The planet's ten biotypes, ordered zonally from the equator to the poles, are described in the book Vegetation zones and climates (Vegetationszonen und Klima, 1977), and are listed in Table 5. 
Table 5. Parameters for the bioclimate types of Walter's classification

\begin{tabular}{|c|c|c|c|c|c|}
\hline TYPE & VEGETATION & T curve & P curve & $\operatorname{Tm}{ }^{\circ} \mathrm{C}$ & $\begin{array}{c}\mathrm{Pm} \\
(\mathrm{mm} / \text { year })\end{array}$ \\
\hline I & $\begin{array}{l}\text { Evergreen tropical rainforest zone } \\
\text { (Equatorial, always humid) }\end{array}$ & Type 1 & Type a & $>20$ & $>1600$ \\
\hline$\|$ & $\begin{array}{l}\text { Tropical vegetation with summer rainfall } \\
\text { (Tropical, with summer rainy season) }\end{array}$ & Type 2 & Type a & $>20$ & $1200-1300$ \\
\hline III & $\begin{array}{l}\text { Vegetation of the arid, subtropical zone. } \\
\text { (Subtropical, dry heat) }\end{array}$ & $\begin{array}{l}\text { Type } 2 \\
\text { or } 3\end{array}$ & Type a & $>20$ & $<100$ \\
\hline IV & $\begin{array}{l}\text { Sclerophyllous vegetation of zones with } \\
\text { winter rainfall }\end{array}$ & Type 4 & Type a & $14-15$ & $500-700$ \\
\hline$\vee$ & $\begin{array}{l}\text { Hot temperate vegetation zone } \\
\text { (Temperate, always humid). Typical } \\
\text { example is the Atlantic forest, with flat } \\
\text { leaves and deciduous plants, but also } \\
\text { certain types of conifers, eucalyptus, } \\
\text { Nothofagus, and Tsugas }\end{array}$ & Type 4 & $\begin{array}{l}\text { Type a } \\
\text { or b }\end{array}$ & 15 & $>1,000$ \\
\hline VI & $\begin{array}{l}\text { Broad-leaved forest zone, green in } \\
\text { summer with a temperate climate (humid } \\
\text { with a cold season). Broad-leaved, } \\
\text { deciduous forest with oak, beech, } \\
\text { maple, hornbeams, birches and other } \\
\text { leafy and coniferous tres }\end{array}$ & $\begin{array}{l}\text { Type } 5 \\
\text { or } 6\end{array}$ & Type a & $8-10$ & $\sim 750$ \\
\hline VII & $\begin{array}{l}\text { Arid vegetation zone of the temperate } \\
\text { climatic zone (arid with a cold season). } \\
\text { Steppes and grasslands }\end{array}$ & $\begin{array}{l}\text { Type } 4 \\
\text { or } 5\end{array}$ & $\begin{array}{l}\text { Type a } \\
\text { or b }\end{array}$ & 12 & $\sim 350$ \\
\hline VIII & $\begin{array}{l}\text { Boreal area with needle-leaved forest } \\
\text { (taiga) }\end{array}$ & $\begin{array}{l}\text { Type } 6 \\
\text { or } 7\end{array}$ & $\begin{array}{l}\text { Type a } \\
\text { or b }\end{array}$ & 5 & $\sim 450-550$ \\
\hline IX & $\begin{array}{l}\text { Arctic tundra area. Tundra and polar } \\
\text { desert }\end{array}$ & $\begin{array}{l}\text { Type } 6 \\
\text { or } 7\end{array}$ & Type a & -5 & $100-200$ \\
\hline$x$ & Mountain climate & Type 8 & $\begin{array}{l}\text { depend } \\
\text { on your } \\
\text { situation }\end{array}$ & $\begin{array}{l}\text { depend } \\
\text { on your } \\
\text { situation }\end{array}$ & $\begin{array}{l}\text { depend on } \\
\text { your } \\
\text { situation }\end{array}$ \\
\hline
\end{tabular}

Source: own elaboration

Lastly, with regard to bioclimatic cartography, we shall mention R.G. Bailey's work (2009) in which he establishes the ecoregions, defined by The Nature Conservancy (TNC) and the World Wildlife Fund (WWF), to help conservation activities for terrestrial ecosystems, which divides the 
earth's surface into eight ecozones, divided in turn into a total of 867 terrestrial ecoregions. Methodologically, Bailey established a classification system on three scales: one of a macroclimatic nature, one meso with geomorphological differentiation (mosaic of landscapes), and one micro edapho-topoclimatic, with 4 domains (Polar, Temperate humid, Dry and Tropical humid), divided into 19 subtypes.

\subsection{Objectives}

The general objective of this study is to develop an analytical and cartographic model of the distribution of the biomes and plant formations, on a multi-scalar level, based on bioclimatic variables and the bioclimatic limits extracted from the Thornthwaite Water Balance (WB) and the Montero de Burgos \& González Rebollar Bioclimatic Balances (BB).

As specific objectives, a comparison will be carried out of the results of the method with two examples from Köppen's climatic classification based on the mappings of Beck et al. (2018). These examples are Panama-Costa Rica and the northeast coast of Brazil. These examples will highlight the expression of the new method on the latitudinal and altitudinal gradient (TalamancaBaru mountain range in Central America) as well as its exposure to the trade winds or the effect of the Central American monsoon.

\section{Materials and methods}

In the method followed, bioclimatic indicators were used to establish the conditions for each plant formation in its corresponding bioclimatic regime. It is based on a geobotanical research method that uses the analysis of parametric data, expressed using the two graphs for water balance (WB) and bioclimatic balance (BB) (Cámara, 2004). Its basis is in the combination of the information on the texture of the geomorphological surface formations (expressed using Store Capacity or water available to plants before saturation of the soil), with the plant cover/depth of roots (Thornthwaite, 1955, 1957). Its cartographic expression is carried out based on continuous surface databases, specifically WorldClim, and it acts as an analytical tool for past or future changes (Figure 1). 
Figure 1. Scheme of the methodology

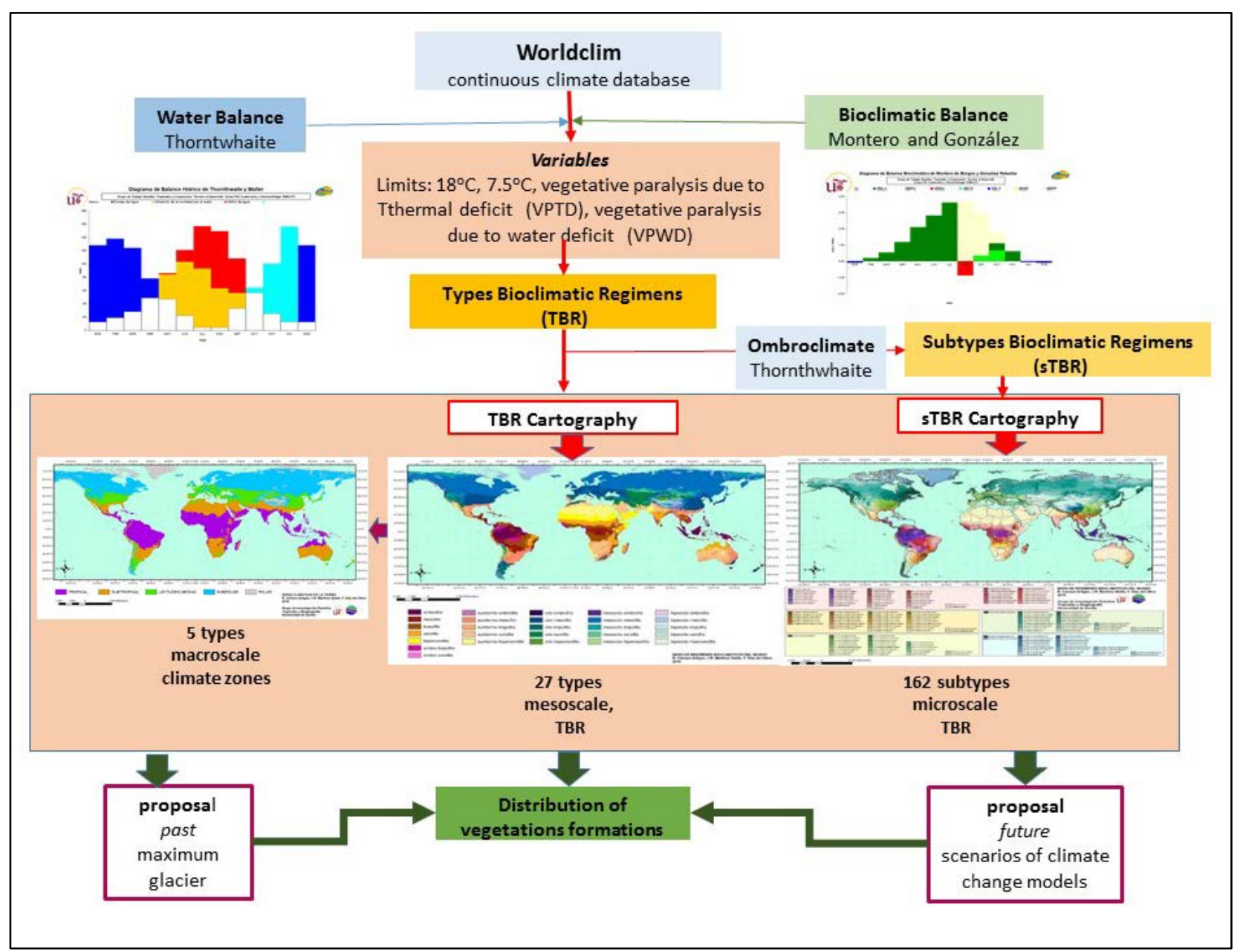

Source: own elaboration

\subsection{WorldClim's raster databases as a tool for analysis}

The analysis of the distribution of plant formations on Earth has been linked to macro (climate), meso (relief) and micro-environmental (soil) factors. In these, the temperature and humidity variables play a fundamental role.

The edaphological factor is not considered in this study due to the scale of detail in processing it, and the altimetric factor is reflected in the data obtained from WorldClim's surface database (http://worldclim.org/version2) which covers the years from the 1950s to 2000 (Fick \& Hijmans, 2017; Hijmans et al., 2005). (Climate data from the Global Historical Climate Network Dataset - GHCN, WMO climatological normals - CLINO, FAO CLIM 2.0, CIAT-Colombia Center for Tropical Agriculture).

For its interpolation, the spline algorithm was used, smoothed by the AUSPLIN package (Hutchinson, 2004), using latitude, longitude and elevation as independent variables. Uncertainty 
is measured using the density of the data from the weather stations and with the elevation bias within each cell.

It is monitored using cross-validation, being greater in mountain areas or areas with low samples. The advantages are: data with a higher resolution, improved elevation data, more stations used, and it provides more information on spatial patterns of data uncertainty (Hijmans et al., 2005). These results were improved for the thermal values using the processing of the MODIS platform (Fick \& Hijmans, 2017), achieving a precision for temperature of $5-15 \%$ (0.07 to $0.17^{\circ} \mathrm{C}$ ). No greater precision was achieved for precipitation. The results of the average temperatures and annual precipitation were compared to other high-resolution layers of climate surfaces in the United States:

- Daymet database with $1 \mathrm{~km}$ precision (30 arcsec) for averages for the years 1980-1997 (https://daymet.ornl.gov//) (Thornton et al., 1997)

- PRISM climate database with $2.5 \mathrm{arcmin}(5 \mathrm{~km})$ of precision for data from 1970-2000 (http://ocs.oregonstate.edu//) (Daly et al., 2002).

Based on the thermal-rainfall characteristics, the seasonal distribution of rains and the existence or otherwise of paralysis of plant activity, it is possible to deepen our knowledge of the mosaic of bioclimatic subtypes in the zonal domains of the Earth. Thus, based on E. Huguet del Villar's classification (1929) (Clements, 1902; Warming, 1909) based on the Thornthwaite Water Balance (WB) (Thornthwaite et al., 1955, 1957) and the Bioclimatic Balances (BB) of Montero de Burgos and González Rebollar (1974), we can identify 27 types of meso-scalar "bioclimatic regimes", grouped into 5 large macro-scale categories of zonal character.

Prentice (1990) evaluated the efficiency of the bioclimatic classifications of Holdridge (1967), Thornthwaite $(1933,1948)$ and Köppen (1936). Although the proposed systems have between 25 and 59 bioclimatic types or classes, none of them correctly predicted more than $40 \%$ of the vegetation types in the field. According to him, the climate-vegetation correlation works better based on extreme climate patterns, and the problem lies in some of these not being represented in these classifications. Prentice adjusted the climate parameters and reached $77 \%$ precision, but only with 29 types (including primary and transitional types).

\subsection{Climate database: water and bioclimatic balances}

To develop this methodology's typologies, 1,500 thermal-rainfall stations were collected from America, Africa, Europe and Asia between the years 1992 and 2018 
(https://www.ncdc.noaa.gov/ which includes data from the National Climatic Data Centre, NOOA), and its application to various studied locations (Cámara, 1997; Cámara, 2004; Cámara et al, 2005; Porto de Lima, 2012; Paladini 2016; Gonzalo, 2018). Drawing up water balances (WB) using Thornthwaite \& Matter's method (Thornthwaite et al., 1955, 1957) and Montero de Burgos \& González Rebollar's bioclimatic balances (BB) (1974) in all the Earth's climatic zones enabled us to establish a typology that we will call bioclimatic regimes that effectively represent the distribution of the large groups of plant formations: tundra, boreal conifer forests, mixed forests, deciduous forests, cold grasslands, hot steppes, subtropical forests and humid and dry tropical forests.

The monthly value obtained for the WB runoff is used to correct the monthly value for useful precipitation ( $p$ ) for plants in the BB. Therefore, the balances are mutually related, and in turn they are related to:

a) the surface formations that sustain the vegetation,

b) the type of vegetation itself in its vertical and horizontal structure.

The ecological valence of the plant formations based on their distribution is connected to the bioclimatic ranges by an environmental characterisation adapted to the seasonal temporal factors (months of the year): thermal-rainfall factors (average T and monthly P), edapho-sedimentological factors (Storage Capacity) and spatial factors (vegetation distribution). We named this environmental characterisation Type of Bioclimatic Regime (TBR). Each of these TBRs is susceptible to new qualifiers as long as the edapho-sedimentological factor and the scale on which it is considered is more precisely described. On a small continental or regional scale $(1: 1,000,000-1: 200,000)$ or medium scale $(1: 50,000)$ the potential values are considered, meaning without restrictions due to the Storage Capacity or plant cover (SC $=400 \mathrm{~mm}$ ) (Thornthwaite et al., 1955-1957). If working on a more detailed scale $(1: 10,000-1: 5,000)$, the real values for coverage and Storage Capacity are considered.

\subsection{Collection of raster layers of types and subtypes of bioclimatic regimes}

For the procedure for calculating and obtaining cartography from the TBRs continuous surfaces database, the WorldClim was used (Fick \& Hijmans, 2017; Hijmans et al, 2005) with the most detailed scale, with 30 seconds $\left(1 \mathrm{~km}^{2}\right)$. Using map algebra with the ArcGis software, the various bioclimatic regimes were obtained. For this, the mapping of months with paralysis of plant activity due to water or temperature, total precipitation, potential evapotranspiration and monthly average temperature were used as variables. Based on these variables, algorithms were used to obtain 
each one of the 27 TBRs. In the same manner, to acquire the 162 subtypes identified from the 27 TBRs (of the 243 that are possible), we used Thornthwaite's Ombrothermic Index as a basis, operating it using a combination of raster layers of bioclimatic regimes and the Ombrothermic Index to obtain the final product (Annex).

\subsection{Bioclimatic variables and limiting factors}

The variables result from the monthly data on precipitation and temperature, with the aim of obtaining more biologically significant data (Tuhkanen, 1980, Mather \& Yoshioka, 1966). The obtained data represent annual trends, seasonality, extremes or limiting environmental factors. These results will affect the distribution of species and in which biotypical form they will appear in the various environments.

There are two key factors in the bioclimatic distribution of plant species, which are temperature and precipitation/soil moisture, as seen in the introduction, based on the limits established for the distribution of plant formations.

Temperature is one of the most important factors for the development of vegetation and life in general (Whittaker, 1962, 1975), as there are specific optimal temperatures for plant development. This may work as an enhancing factor if found within certain optimum limits, but it can also be a very important limiting factor in the environment, if it is outside of these optimum parameters, either due to being over or under (PET very high and greater than precipitation), and it becomes the first situation responsible for the paralysis of plant activity due to temperature. This factor is distributed latitudinally with the angle of incidence of solar rays (according to latitude) and with regards to altitude (thermal gradient at height) in topography.

With regards to moisture, we are referring both to the total precipitation that falls in a location throughout the year and its distribution throughout each year, as well as the moisture retained by the soil or its status in terms of excess or deficit. Like temperature, precipitation can behave as an enhancer or limiter of the plant's ability to grow in a location, due to its distribution and quantity. When precipitation provides sufficient moisture for optimum conditions together with physiographic, edaphological and thermal conditions that are also optimum, it will further enable the development of the vegetation where it is located, provoking an increase in biomass.

However, when precipitation is scarce, very scarce or appears in a very irregular manner throughout the year, the lack of moisture works as a limiting factor and triggers the paralysis of plant activity due to lack of water. 
It must be recalled, with regards to edaphic moisture, that the moisture storage capacity of the soil is defined by the texture of the substrate that forms this soil and the depth of the roots of the vegetation present in this location (Thornthwaite et al., 1955, 1957).

Nevertheless, the temperature, precipitation and moisture are not the only factors that are responsible for the plant's establishment and development. As we have mentioned, they are the most significant bioclimatic factors, but there are other ones such as altimetry, orientation of slopes (suntrap/shady, windward/leeward) and the type of edaphology existing that also affect in a local and very important way the manner and type of vegetation that is established in a location.

The most remarkable bioclimatic factors considered in this methodology are:

- The optimum temperature for the assimilation and formation of plant matter by photosynthesis, which is between 25 and $28^{\circ} \mathrm{C}$ for its growth (Meyer et al., 1966) and not close to $30^{\circ} \mathrm{C}$, which is when the carbon gas content of the atmosphere is strongest (Tricart, 1974 p. 24). When the temperature exceeds this optimum, assimilation and an essential part of the biological functions reduce, provoking the paralysis of plant activity due to water. The optimum for animal respiration takes place between 35 and $50{ }^{\circ} \mathrm{C}$ (Medina, 1977), but the optimum for plants is between 20 y $25^{\circ} \mathrm{C}$, with maximum assimilation, and respiration-transpiration is not very intense. At higher temperatures, assimilation reduces whilst consumption of carbohydrates, broken down into $\mathrm{CO}_{2}$ and $\mathrm{H}_{2} \mathrm{O}$ by respiration, increases. At the same time, transpiration increases, which produces a loss of water that activates the extraction of water from the soil, which will result in the lowering of mineral matter. Therefore, in the hot months, the plants' metabolism changes, reducing respiration and transpiration, with the loss of their leaves (deciduous) and adopting xerophytic traits to combat the excess of respiration and transpiration (Touchette \& Burkholder, 2000).

- Limit of $18^{\circ} \mathrm{C}$, established by De Candolle (1874), for the isotherm of the coldest month that indicates the tropical climates in relation to tropical vegetation, ecophysiologically justified in the previous point.

- Limit of $7.5^{\circ} \mathrm{C}$ for the isotherm of the coldest month that marks the division between the subtropical and cold climates, in which there is the paralysis of plant activity due to temperature for at least one month. It is based on the hypothesis that, generally, in the majority of plants, stable plant activity begins at $6{ }^{\circ} \mathrm{C}$ in terms of monthly average 
temperature. Experimentally, Montero de Burgos \& González Rebollar (1974, p. 18) show that from $7.5^{\circ} \mathrm{C}$, the speed of growth is proportional to $\left(\mathrm{T}-7.5^{\circ} \mathrm{C}\right)$, and total growth will be proportional to $\left(\mathrm{T}-7.5^{\circ} \mathrm{C}\right)$ and time. Graphically, on the bioclimatic diagrams, plant activity is proportional to the area between the temperature curve and $T=7.5^{\circ} \mathrm{C}$ and hence "the maximum plant activity that can be provided by the climate is measured by the area between the monthly average temperature curve and the straight line at $7.5^{\circ} \mathrm{C}^{\prime \prime}$ and this area is called the Potential Bioclimatic Intensity (PBI). If the PBI is negative, it is null, and plant activity is null, triggering paralysis of plant activity due to temperature.

- Limit of $-2{ }^{\circ} \mathrm{C}$ related to the conservation of the permafrost (French Shcur, 2010; Barry, 2017) which indicates hipercriophyllia.

- Paralysis of plant activity due to lack of water based on the relationship between potential evapotranspiration and residual evapotranspiration (PET/e $=\phi)$. Between the maximum plant activity and its death, there is a stage where plant activity is paralysed. This has no negative physiological effects, and it results in the closure of stoma. When sap is retained due to drought, there is reduced evapotranspiration and if the drought continues the transpiration reduces, albeit slowly. This reduced evapotranspiration during the paralysis of the plant activity is called by Montero and González (1974, p. 28) residual evapotranspiration and they define it as potential evapotranspiration with halted sap. Experimentally, (Montero \& González, 1974; Montero \& García, 1981) show that this relationship with the hypothesis of $\phi$ is 5 and 6 , which means a correction value between $e=0.2 *$ PET and $e=0.16666 \ldots *$ PET. For the bioclimatic diagrams they chose the value of 5 due to its greater representivity. Therefore in the months in which P-PET $<0$, residual evaporation (e) works, with paralysis of plant activity, which is equivalent to e $=0.2$ *PET, so that in the months in which P-0.2*PET<0 is true, plant activity will be Vegetative Paralysis due to Water Deficit (VPWD).

\section{Results and discussion}

The TBRs are obtained by algorithms on ArcGis (Appendice A). The combination of the bioclimatic regimes and the precipitation zones gives the 155 subtypes of TBRs, which enable specific formations to be established, on a more detailed scale, with various moisture ranges within a single TBR. The cartographic result is shown on the map in Figure 2 and on the website https://kerdoc01.cica.es/erosionvisor/biomap.html 
Figure 2. Map and legend of the 155 bioclimatic regime subtypes
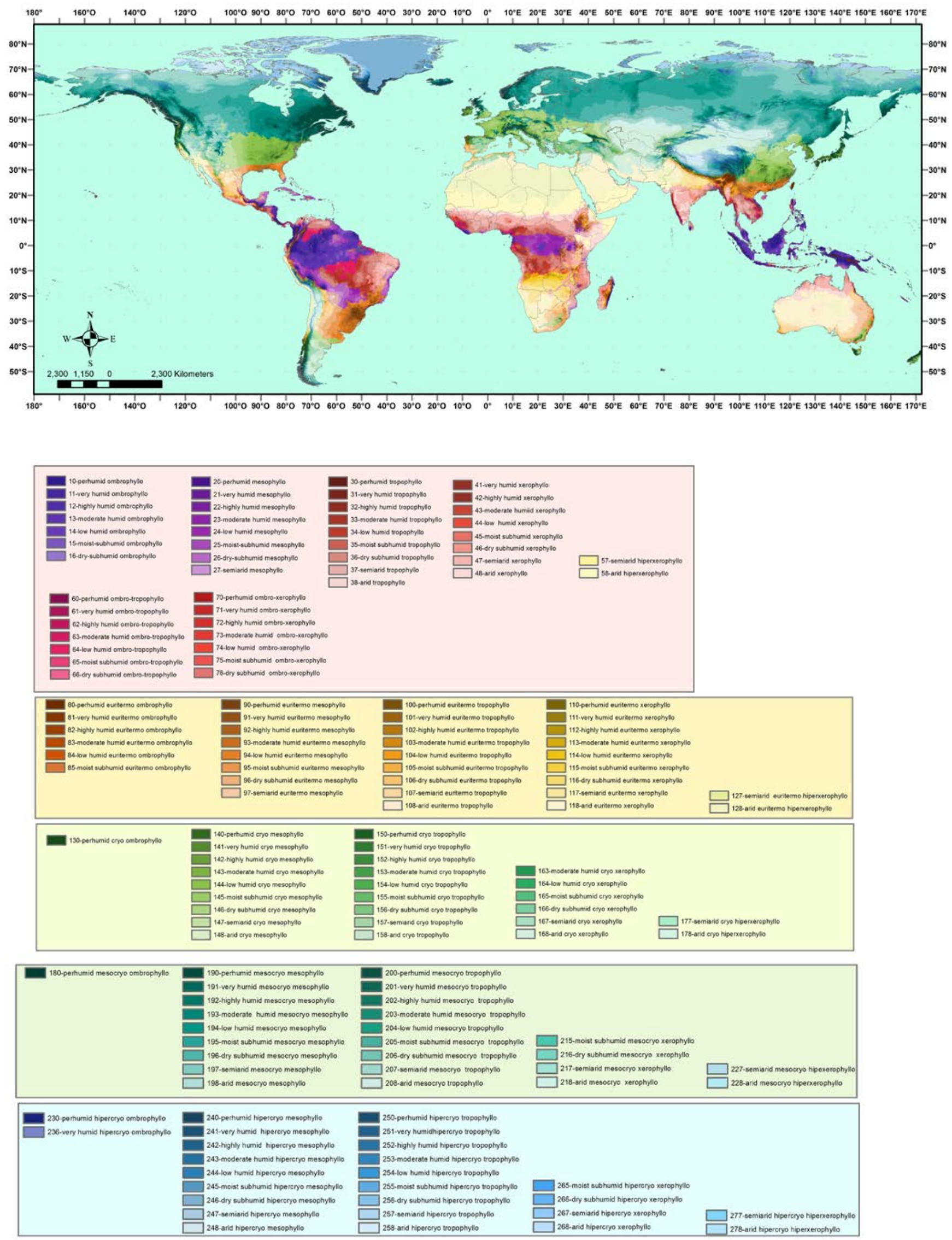

Source: own elaboration 


\subsection{Distribution models for plant formations according to bioclimatic regimes: bioclimatic types}

Based on the data from the thermal-rainfall stations and their WB and BB we have identified the limits of the temperature and precipitation variables on the TBRs. The vegetation that is located in a place based on its thermal and water limitation is defined as follows based on the proposals of Schimper (1903), Warming (1909) and Huguet del Villar (1929) and the nomenclature proposed by Clements (1909):

- Termophyllia: they are located in places without thermal restrictions, and with a small annual thermal range

- Euritermophyllia: there is significant thermal variation during the year and in each month, but without there being paralysis of plant activity due to temperature.

- Cryophyllia: that which is present when there is a short or medium paralysis due to temperature, from 1 to 5 months.

- Mesocryophyllia: those which are found in locations where this thermal paralysis is from 6 to 9 months, which affects the distribution of broad-leaved plants.

- Hipercriophyllia: that limit the development of woody species, from 10 to 12 months of paralysis of plant activity due to temperature. Based on the stated characteristics, 5 broad categories were identified, that are macro-scalar and of a zonal nature (Figure 3) and 27 types of mesoscalar "bioclimatic regimes" (Figure 4). 
Figure 3. Zonal units based on the classification of bioclimatic regimes.

Prepared by the authors using the WorldClim database

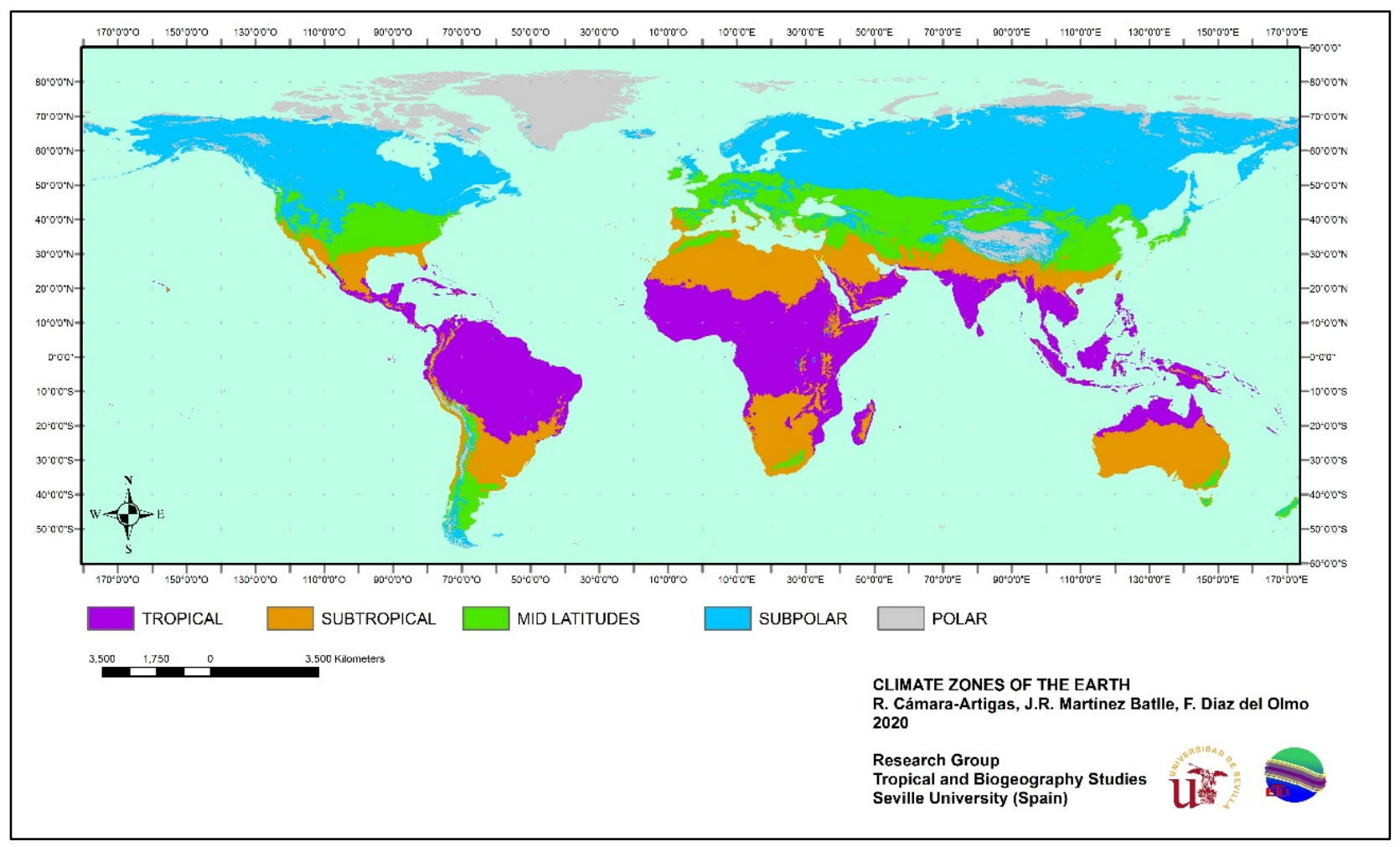

Source: own elaboration

As with temperature, based on the limitation implied by the lack of water in an area, different situations will be presented also in accordance with the proposals of Schimper (1903), Warming (1909) and Huguet del Villar (1929):

- Ombrophyllia: that are present in locations where there is no lack of water at any time of the year (precipitation is greater than $60 \mathrm{~mm}$ in all months):

- Mesophyllia: there is a greater lack of water, but without this implying paralysis of plant activity. Some months there can be a lack of water in the soil.

- Tropophyllia: when there is an edaphic water deficit that provokes paralysis of plant activity, as long as this lasts between 1 and 4 months. In the case of the tropics, this refers to tropical deciduous forests, that may have needles.

- Xerophyllia: if the water conditions lead to a longer paralysis of plant activity, from 5 to 8 months. Shrubs and crassulaceae, with spiny features, predominate.

- Hiperxerophyllia: with 9 to 12 months of paralysis of plant activity due to water, with shrublike vegetation and open crassulaceae, very disperse, or practically without it. 
Figure 4. Map of the 27 TBRs. Prepared by the authors using the WorldClim database

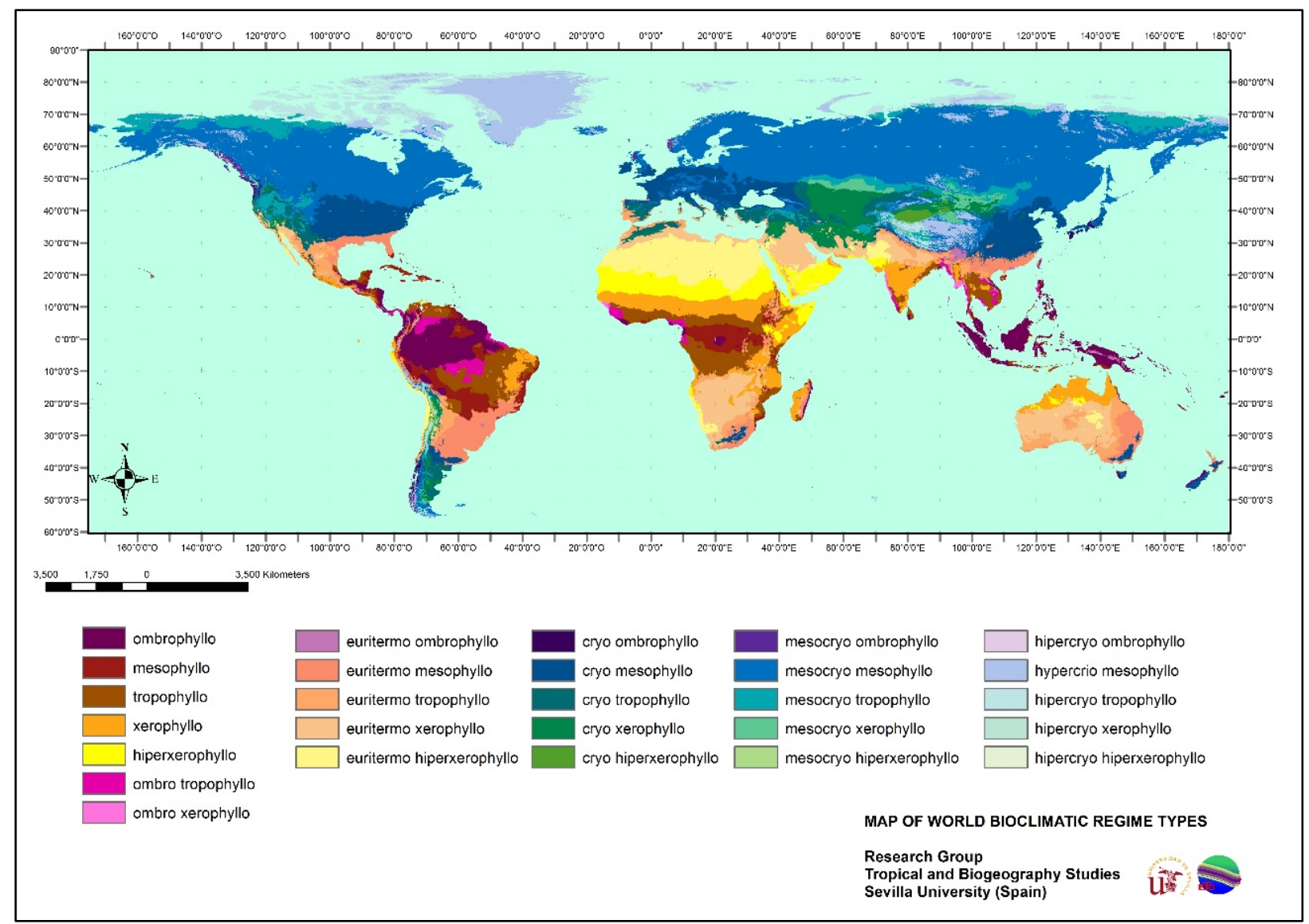

Source: own elaboration

This does not mean that the opposite situation, i.e. an excess of water in the soil (with a regime of seasonal or continuous flooding) is not also a very important limiting factor for the development or establishing of the vegetation in a specific location. Species adopt strategies for living in these environments, as is the case of the holohidrophyillas and helophyllas species (Huguet del Villar, 1929), such as mangroves, subtropical and tropical forest swamps, salt marshes and marsh formations, among others.

a) TROPICAL ZONE (around $24^{\circ}$ latitude $\mathrm{N}$ and S) (Table 6). Tropical humid rainforests, semideciduous and dry forests, savannahs, shrub formations, tropical deserts. Average annual temperature of every month above $18{ }^{\circ} \mathrm{C}$. No vegetative paralysis due to water deficit (VPWD) or temperature (VPTD). There are five types with two special, Ombro-tropophyllia and Ombroxerophyllo, which correspond to situations dominated by the monsoon or in the transition from ombrophyllia to plant formations with paralysis of plant activity due to lack of water (Amazonia and the Congo Basin). 
Table 6. Tropical bioclimatic regimes.

\begin{tabular}{|c|c|c|c|}
\hline $\begin{array}{c}\text { BIOCLIMATIC } \\
\text { REGIMEN }\end{array}$ & $\begin{array}{c}\text { MONTHS } \\
\text { OF VPWD }\end{array}$ & MONTHS OF VPTD & $\begin{array}{c}\text { ANNUAL } \\
\text { PRECIP. (MM) }\end{array}$ \\
\hline Ombrophyllo & 0 & 0 & $>2000$ \\
\hline Mesophyllo & 0 & 0 & $<2000$ \\
\hline Tropophyllo & $1-4$ & 0 & $<2000$ \\
\hline Xerophyllo & $5-8$ & 0 & $<2000$ \\
\hline Hiperxerophyllo & $9-12$ & 0 & $<2000$ \\
\hline Ombro-tropophyllo & $1-4$ & 0 & $>2000$ \\
\hline Ombro-xerophyllo & $5-8$ & 0 & $>2000$ \\
\hline
\end{tabular}

Source: own elaboration

b) SUBTROPICAL ZONE (between approximately 25 and $42^{\circ}$ latitude $\mathrm{N}$ and S) (Table 7). Sclerophyllous, laurisilva forests, hot steppes and subtropical deserts. At least one month with monthly average temperature below $18^{\circ} \mathrm{C}$. All months above the monthly average temperature of $7.5^{\circ} \mathrm{C}\left(\mathrm{Tf}>7.5^{\circ} \mathrm{C}\right)$.

Table 7. Subtropical bioclimatic regimes

\begin{tabular}{|c|c|c|c|}
\hline BIOCLIMATIC REGIMEN & $\begin{array}{c}\text { MONTHS OF } \\
\text { VPWD }\end{array}$ & $\begin{array}{c}\text { MONTHS OF } \\
\text { VPTD }\end{array}$ & $\begin{array}{c}\text { ANNUAL } \\
\text { PRECIP. (MM) }\end{array}$ \\
\hline Euritermo ombrophyllo & 0 & 0 & $>2000$ \\
\hline Euritermo mesophyllo & 0 & 0 & $<2000$ \\
\hline Euritermo tropophyllo & $1-4$ & 0 & $<2000$ \\
\hline Euritermo xerophyllo & $5-8$ & 0 & $<2000$ \\
\hline Euritermo hiperxerophyllo & $9-12$ & 0 & $<2000$ \\
\hline
\end{tabular}

Source: own elaboration

c) MIDDLE LATITUDE ZONE (between approximately 35 and $55^{\circ}$ latitude $\mathrm{N}$ and S) (Table 8). Deciduous forests, mixed deciduous-coniferous forests and cold steppes. All months with an average temperature above $0^{\circ} \mathrm{C}$ (critical temperature) and between 1 and 5 months with monthly average temperature below $7.5^{\circ} \mathrm{C}:-3^{\circ} \mathrm{C}<\mathrm{Tf}<7.5^{\circ} \mathrm{C}$. 
Table 8. Bioclimatic regimes of middle latitudes

\begin{tabular}{|c|c|c|c|}
\hline BIOCLIMATIC REGIMEN & $\begin{array}{c}\text { MONTHS OF } \\
\text { VPWD }\end{array}$ & $\begin{array}{c}\text { MONTHS OF } \\
\text { VPTD }\end{array}$ & $\begin{array}{c}\text { ANNUAL } \\
\text { PRECIP. (MM) }\end{array}$ \\
\hline Cryo ombrophyllo & 0 & $1-5$ & $>2000$ \\
\hline Cryo mesophyllo & 0 & $1-5$ & $<2000$ \\
\hline Cryo tropophyllo & $1-4$ & $1-5$ & $<2000$ \\
\hline Cryo xerophyllo & $5-8$ & $1-5$ & $<2000$ \\
\hline Cryo hiperxerophyllo & $9-12$ & $1-5$ & $<2000$ \\
\hline
\end{tabular}

Source: own elaboration

d) SUBPOLAR ZONE (between 40 and $60^{\circ}$ latitude $\mathrm{N}$ and S) (Table 9). Coniferous forests and mixed coniferous-deciduous forests. Not all months with an average temperature above $0^{\circ} \mathrm{C}$ (critical temperature) and 6 to 9 months with a monthly average temperature below $7.5^{\circ} \mathrm{C}$ $\left(\mathrm{Tf}<\mathrm{O}{ }^{\circ} \mathrm{C}\right)$.

Table 9. Bioclimatic regimes of middle latitudes

\begin{tabular}{|c|c|c|c|}
\hline BIOCLIMATIC REGIMEN & $\begin{array}{c}\text { MONTHS OF } \\
\text { VPWD }\end{array}$ & $\begin{array}{c}\text { MONTHS OF } \\
\text { VPTD }\end{array}$ & $\begin{array}{c}\text { ANNUAL } \\
\text { PRECIP. (MM) }\end{array}$ \\
\hline Mesocryo ombrophyllo & 0 & $6-9$ & $>2000$ \\
\hline Mesocryo mesophyllo & 0 & $6-9$ & $<2000$ \\
\hline Mesocryo tropophyllo & $1-4$ & $6-9$ & $<2000$ \\
\hline Mesocryo xerophyllo & $5-8$ & $6-9$ & $<2000$ \\
\hline Mesocryo hiperxerophyllo & $9-12$ & $6-9$ & $<2000$ \\
\hline
\end{tabular}

Source: own elaboration

e) POLAR ZONE (between 60 and $90^{\circ}$ latitude $\mathrm{N}$ and S) (Table 10). Tundra, wooded tundra and high-altitude pastures on mountains. There are months with an average temperature below $0{ }^{\circ} \mathrm{C}$ (critical temperature) and from 10 to 12 months with an average monthly temperature below $7.5^{\circ} \mathrm{C}$. There are months with an average temperature below $-3^{\circ} \mathrm{C}$. 
Table 10. Polar bioclimatic regimes.

\begin{tabular}{|c|c|c|c|}
\hline BIOCLIMATIC REGIMEN & $\begin{array}{c}\text { MONTHS OF } \\
\text { VPWD }\end{array}$ & $\begin{array}{c}\text { MONTHS OF } \\
\text { VPTD }\end{array}$ & $\begin{array}{c}\text { ANNUAL } \\
\text { PRECIP. (MM) }\end{array}$ \\
\hline Hipercryo ombrophyllo & 0 & $10-12$ & $>2000$ \\
\hline Hipercryo mesophyllo & 0 & $10-12$ & $<2000$ \\
\hline Hipercryo tropophyllo & $1-4$ & $10-12$ & $<2000$ \\
\hline Hipercryo xerophyllo & $5-8$ & $10-12$ & $<2000$ \\
\hline Hipercryo hiperxerophyllo & $9-12$ & $10-12$ & $<200$ \\
\hline
\end{tabular}

Source: own elaboration

\subsection{Discussion}

The existing classifications that we have reviewed previously are useful on a continental and regional scale and describe the vegetation in a general manner, using the factors of annual water and temperature levels (solar radiation, average monthly and annual temperatures, availability of water in the soil, evapotranspiration).

Our 27 types of TBR have been compared with the 13 WWF ecoregions (Terrestrial Ecoregions of the World-TEOW) (Olson et al. 2001), using the combine tool from ArcGis. It has given us 256 types of combination. The affinity score is $96 \%$ of the surface. Of the $4 \%$ difference, $2.3 \%$ is due to differences in plant formation, and $1.7 \%$ to differences in the bioclimatic domain:

- $0.5 \%$ is temperate bioclimate in WWF and subtropical in TBR;

- $0.8 \%$ is Mediterranean bioclimate in WWF and temperate in TBR;

- $0.04 \%$ is tropical and subtropical in WWF compared to temperate in TBR (generally refers to mountain regions in tropical environments);

- $0.3 \%$ is tundra in WWF but taiga in TBR;

- $0.03 \%$ is Mediterranean in WWF but taiga in TBR.

In the majority of cases this is an issue of scale, as mountain areas that correspond to another TBR are included in a bioclimatic regime. The percentage of tundra for taiga, two adjacent biomes, refers more to transitional areas.

With regard to parameters, we set the isotherm for tropical climates at $18{ }^{\circ} \mathrm{C}$, as this is an accepted value for the majority of bioclimatic classifications, which is set at $18{ }^{\circ} \mathrm{C}$ in classifications 
such as that of Miller (1951), or $20^{\circ} \mathrm{C}$ in Walter's classification (1977). The isotherm of $10{ }^{\circ} \mathrm{C}$ for the cold stations is in the region of the $7.5^{\circ} \mathrm{C}$ that we advocated based on the bioclimatic diagrams' reasoning of vegetative paralysis due to thermal deficit (VPTD). The water parameters are defined by the PET-precipitation relationship that mark the period of vegetative paralysis due to water deficit (VPWD) in the bioclimatic balances. The stations created properly indicate the types of plant formations based on these parameters. Miller's values of 6 months below $6{ }^{\circ} \mathrm{C}$ match our limit between criophyllo and mesophyllo.

Let us now discuss the results of the bioclimatic regimes (subtypes) with Köppen's classification based on the maps created by Beck et al. (2018). We chose two examples: the Isthmus of Panama and northeast Brazil.

a) The Isthmus of Panama

In this case (Figure 4), Köppen identified 6 types, three of them related to the mountain (Cwb, $\mathrm{Cfb}$ and $\mathrm{ET}$ ). The other three refer to sea-level areas with jungle climates (Af), forests with monsoons (Am) and savannahs (Aw). The TBR subtypes, in turn, identify 16 types, 14 at sea level and 4 on the mountain: one subtropical (ombrophyllo perhumid), and another 3 that are temperate-cold (cryo ombrophyllo perhumid, hipercryo tropophyllo perhumid, and hipercryo ombrophyllo perhumid). The 14 subtypes of bioclimatic regimes are grouped into:

- different moisture conditions for tropical rainforests (ombrophyllo) that equate to the Af climate;

- two types of dry, deciduous forests (tropophyllo) similar to Aw;

- six types of forests with monsoons with various moisture ranges (ombro tropophyllo) that are similar to Köppen's Am.

The areas practically coincide, with the exception that the map of bioclimatic regimes is carried out in greater detail, including the middle mountainous areas, and greater detail on moisture transfer between the different types of altitudinal zonation (ombrophyllo, ombro tropophyllo and tropophyllo). In the medium to high-altitude mountain areas:

- Subtropical Cwb equivalent to ombrophyllo perhumid (cloud forests),

- Cold temperate Cfb in turn also equivalent to cryo ombrophyllo perhumid (Quercus forests),

- ET or mountain tundra climate that corresponds to the moors (hipercryo tropophyllo perhumid, and hipercryo ombrophyllo perhumid). 
Figure 4. Comparison of the cartographic results between TBR subtypes and Köppen's classification in the Isthmus of Panama

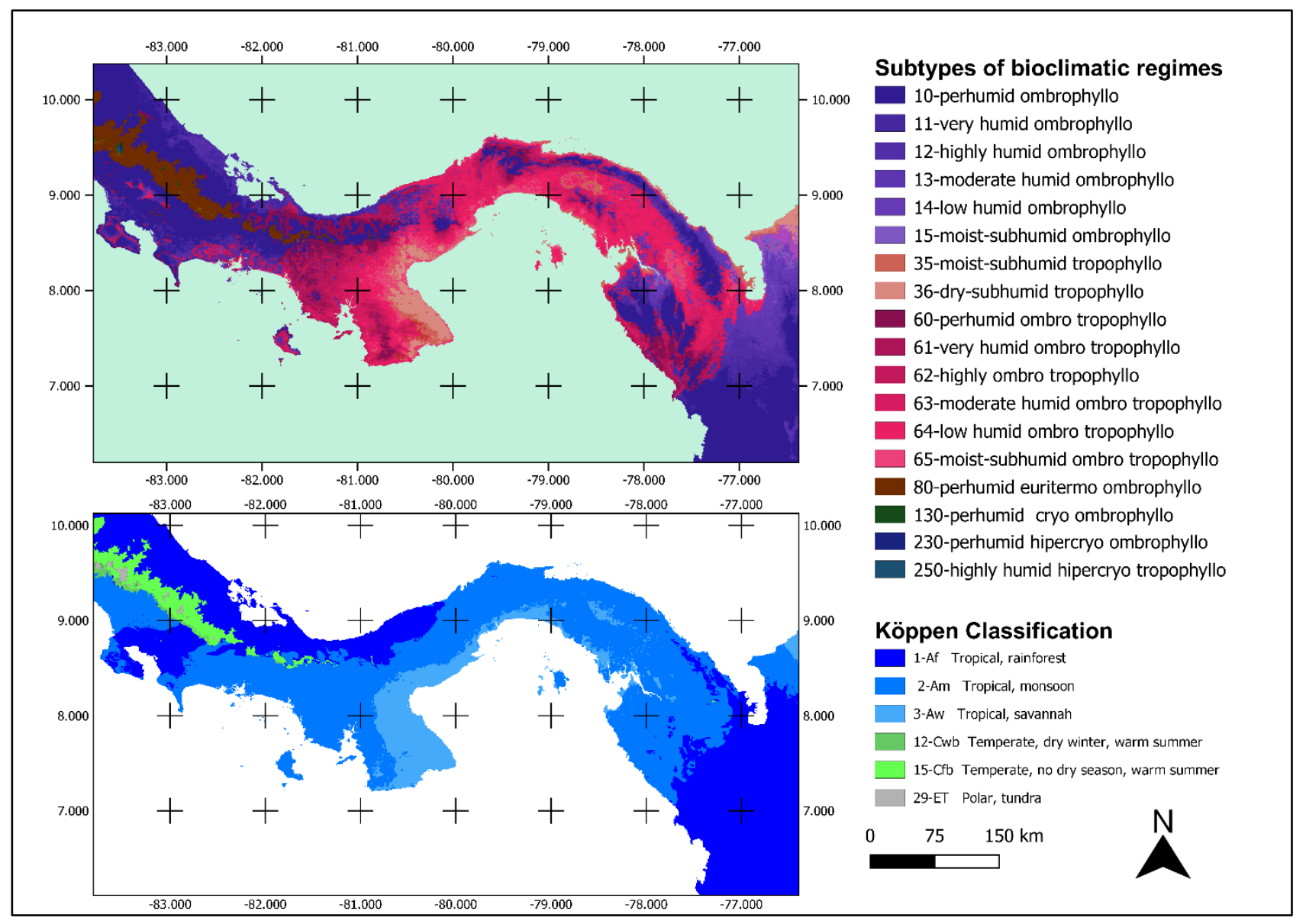

Source: own elaboration based on WorldClim and Beck et al (2018)

b) Northeast Brazil (Figure 5)

Köppen identified 4 types: Am (monsoon tropical), Aw (savannah), BWh (hot desert) and BSh (hot steppe), none of them on a mountain or similar to $A w$ in the interior. There are 13 recognised TBRs, grouped by subtypes:

- ombrophyllos (equivalent to Af) with tropical humid forests, in our case Atlantic Forest);

- mesophyllos that correspond to Köppen's Aw and that reflect Atlantic Forest and highaltitude wetland plants, situations and not that of the savannah;

- tropophyllos with closed vegetation that once again coincides with Köppen's Aw, more in tune here, and which coincides with low to medium topographies (inselbergs) of the Borborema Plateau (tropophyllo moist-subhumid and dry-subhumid);

- tropophyllo dry subhumid, semiarid and arid coinciding with the caatinga and with Köppen's BSh; 
- tropophyllo arid with open shrub-like vegetation related to BWh;

Finally, we have two subtropical subtypes (euritermo mesophyllothat coincide with the medium mountain topographies with ancient vegetation of wetland plants), which in Köppen's classification are Aw.

Figure 5. Comparison of the cartographic results showing TBR subtypes and Köppen's classification in northeast Brazil

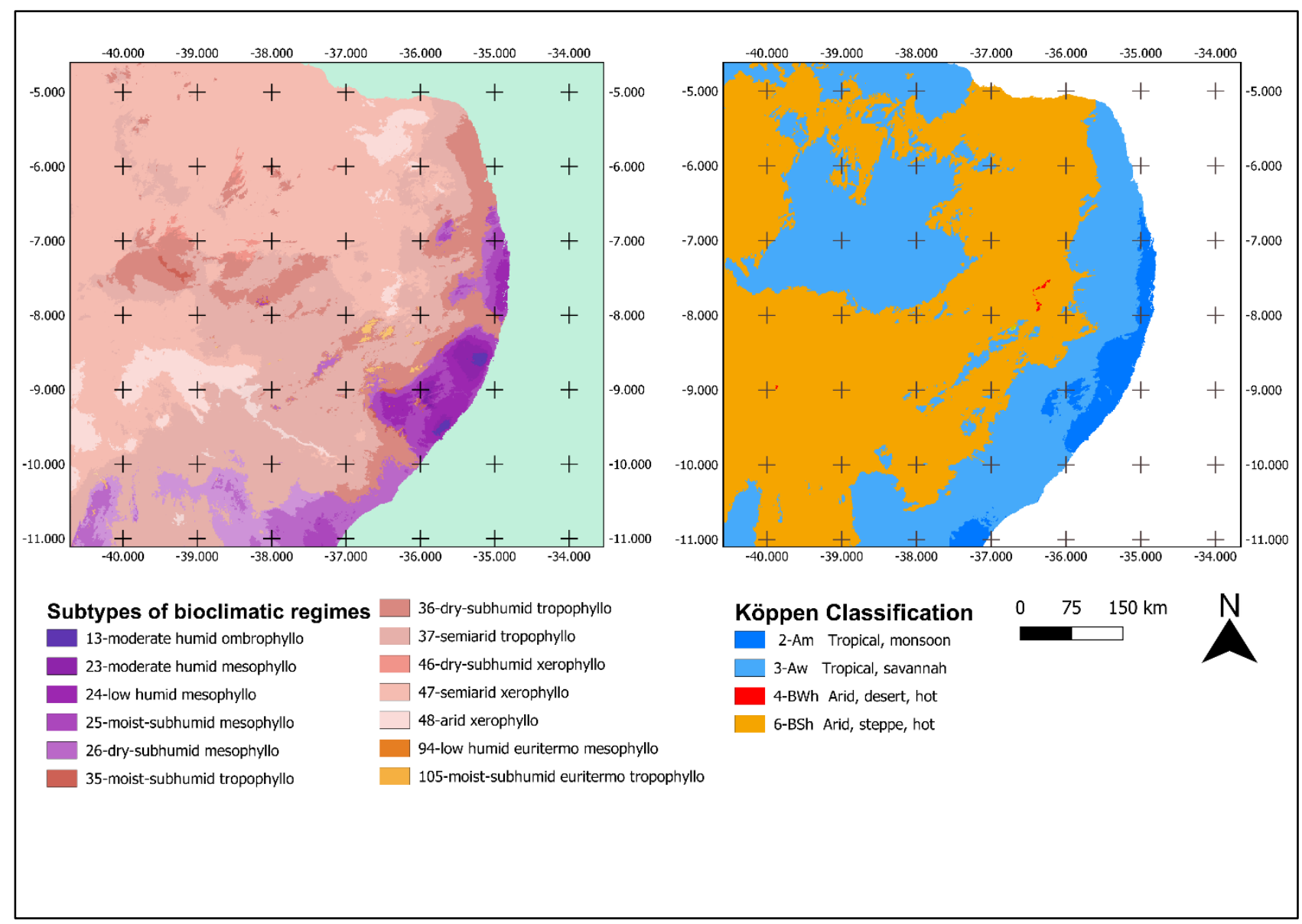

Source: own elaboration based on WorldClim and Beck et al (2018)

Considering these examples, it has been shown that the classification of bioclimatic regimes into types and subtypes is more narrow than that obtained based on Köppen's climatic classifications, in particular with regard to mountain systems, and in the variation of the ombroclimatic subtypes within each type of bioclimatic regime, providing greater scope to explain the distribution of various plant formations within a single biome. 


\section{Conclusions}

With this bioclimatic regime methodology, a multi-scalar classification has been identified on the following levels:

a) zonal (macroscale) with five types: tropical, subtropical (euritermo), temperate (cryo), subpolar (mesocryo) and polar (hypercryo);

b) regional (mesoscale) with 27 types, the bioclimatic regimes per se (29 from the cited study by Prentice)

c) and on a local level with the plant formations (microscale) with 162 subtypes, which is conditional on the lithology of the soil, exposure of the topography to wind and sunshine (Bailey, 2009), and which is obtained with the combination of TBRs and ombroclimates.

Each zonal group of the 5 groups of bioclimatic regimes can be related to a biome whose differentiation in terms of moisture or temperature gives us very different plant formations:

Tropical areas with plant formations that are very moist (jungles) to those that are very dry (tropical deserts, passing through dry forests, savannahs and monsoon forests).

- Subtropical areas with sclerophyllous Mediterranean plant formations and eastern subtropical areas that are moister, which include hot steppes and subtropical deserts.

- The temperate area with deciduous forests and mixed deciduous and coniferous forests and herbaceous formations (cold steppes and grasslands).

- Subpolar areas with forests of dominant conifers (taiga) and mixed forests of conifers and deciduous trees, and formations with herbaceous plants transitioning to coniferous forests.

- Polar areas with tundra and transitional areas between tundra and coniferous forests or deciduous forests with birches.

The new aspect of the method, beyond providing a bioclimatic classification with reference to broad types of vegetation, is that this is based on analytical data attributed to a certain area with a database, WorldClim, which enables the following to be established:

- a multi-scalar approach,

- the changes to these overall units of vegetation in the past (last glacial maximum, last interglacial) or future climate change scenarios, as provided by the databases used.

Therefore, it generates an analytical map whose unit limits are due to the bioclimatic variables, mainly temperature, precipitation and paralysis of plant activity due to water and temperature. 
The important thing about this method is that it will give better results the lower the level of error or uncertainty in the database used. As the reliability of these is improved in mountainous areas or regions with few weather stations, the potential distribution of identified plant formations will be more precise with each type and subtype of TBR.

The use of continuous surface climatic databases, especially in mountain areas, enables the contrast between the types of bioclimatic regimes to be represented according to whether the slopes are facing north or south in subtropical to high latitudes, or upwind or downwind at intertropical latitudes.

Mountain data is the most uncertain, according to the interpolation models. Therefore, this is very important progress facing the lack of representation of the altitudinal zonation of mountains in other climatic and bioclimatic models, which are included in a "mountain areas or zones" section.

This methodology presents new perspectives as a script in the R software as it can generate the bioclimatic and water balance diagrams inspired on data from the thermal-rainfall stations. The mapping of the TBRs based on continuous surface territorial databases of climate data means that the maps can be automatically produced based on the scale of the provided database. This improves the detail of the information generated if it is of a national or regional nature, being able to consider the Store Capacity of the soils from soil texture maps and vertical and horizontal vegetation structure maps that can be obtained on a local scale.

Acknowledgements: This article is a contribution by the research groups RNM-915 and RNM273 (Junta de Andalucía). The contents of this article have been benefited from multiple research and international development cooperation projects. The authors are especially grateful for the support provided by the projects carried out in Panama ('Plan de Desarrollo sostenible del Golfo de Montijo, Panamá (2001-2003)', Araucaria Program, AECID-Fondo Mixto HispanoPanameño), Brazil (Proyecto Integrado PCI 'Recursos y manejo del Territorio y del agua en la Cuenca Hidrográfica del Río Paraiba: disponibilidad y uso para el desarrollo de las comunidades locales', AECID. 2011-2013), and the research projects under the Spanish National Plan (036/2008; 2008-2011) and (CSO2011-24424; 2011-2014). Since 1989, the technical cooperation with other countries allowed us to sketch out what will be the results of this article (Argentina, Bolivia, Burkina Faso, Chile, Colombia, Costa Rica, Dominican Republic, Equatorial Guinea, Mauritania, Mexico, Morocco and Philippines). Authors are thankful to this article's reviewers by their observations and/or recommendations. 
Authorship statement: The authors declare no conflict of interest. The participation of the authors in the article is as follows. The article has been coordinated by R. Cámara. R. Cámara Artigas: conceptualization, methodology, software programming, validation and verification, formal analysis, research, writing, first draft, review and editing, visualization. F. Díaz del Olmo: validation and verification; writing, review and editing, visualization. J.R. Martínez Batlle: software programming, validation and verification, formal analysis. 


\section{References}

Bagnouls, F., \& Gaussen, H. (1957). Les climats biologiques et leur classification. Annales de Geographie, 355, 193-220. https://doi.org/10.3406/geo.1957.18273

Bailey R.G. (2009). Ecosystem Geography. From Ecoregions to Sites. Springer. http://dx.doi.org/10.1007/978-0-387-89516-1

Barry, R.G. (2017). The Artic criosphere in the twenty-first century. Geographicak Review, 107(1), 69-88. https://doi.org/10.1111/gere. 12227

Beck, H.E., Zimmermann, N.E. McVicar T.R., Vergopolan N., Berg A., \& Wood E.F. (2018). Present and future Köppen-Geiger climate classification maps at 1-km resolution. Nature Scientific Data. https://doi.org/10.1038/sdata.2018.214

Brockmann-Jerosch, H. (1907). Die Flora des Puschlav (Bezirk Bernina, Kanton Graubiinden) und ihre Pflanzengesellschaften. Leipzig.

Brockmann-Jerosch, H., \& Rübel, E. (1912). Die Einteilung der Pflanzengesellschaften nach ökologisch-physiognomischen Gesichtspunkten. Leipzig.

Cámara, R. (1997). República Dominicana: Dinámica del medio físico en la región Caribe (Geografía Física, sabanas y litoral). Aportación al conocimiento de la tropicalidad insular (Doctoral dissertation, University of Seville). Retrieved from https://idus.us.es/xmlui/handle/11441/85112

Cámara, R. (2004). Escalonamiento Bioclimático, Regímenes Ecodinámicos y Formaciones Vegetales de la Isla de la Española en República Dominicana. In J.M. Panareda, E. Arocena \& C. Sanz (Eds.), Estudios en Biogeografía 2004: libro homenaje a Jose Manuel Rubio y Jesús García (pp. 39-58). Terrassa, Spain. Servei de Publications de la Universitat de Girona. Retrieved from

http://titulaciongeografiasevilla.es/contenidos/profesores/publicaciones/archivos/RDregimes.pdf

Cámara R., Martínez J.R., \& Díaz del Olmo F. (2005). Desarrollo sostenible y Medio Ambiente en República Dominicana. Medios Naturales, manejo histórico, conservación y protección. Escuela de Estudios Hispano-Americanos (CSIC) y Universidad de Sevilla. Madrid.

Clements, F.E. (1909). Greek and Latin in Biological Nomenclature. Lincoln. https://doi.org/10.5962/bhl.title.33675 
Daly, C., Gibson, W.P., Taylor, G.H., Johnson, G.L., \& Pasteris, P. (2002). A knowledge-based approach to the statistical mapping of climate. Climate Research. 22, 99113. https://doi.org/10.3354/cr022099

De Candolle, A. (1874). Constitution dans le règne végétal des groupes physiologiques applicables à la géographie botanique ancienne et moderne. Geneva.

Diels, L. (1908). Pflanzengeographie. Sammlung Göschen, (389), p. 4.

Drude, O. (1890). Handbuch der Pflamzengeographie. Retrieved from http://www.deutschestextarchiv.de/book/show/drude_pflanzengeographie_1890

Dune, T., \& Leopold, L.B. (1978). Water in Environmental Planning. Iss. W. H. Freeman. San Francisco.

Elhaï, H. (1968). Biogéographie. Paris, Librairie Armand Colin.

Ellenberg, H., \& Mueller-Dombois, D. (1967). Tentative physiognomic-ecological classification of plant formations of the earth. Berichte des Geobotanischen Institutes der Eidg. Techn. Hochschule, Stiffung Rübel, 37, 21-46. Rerieved from https://www.e-periodica.ch/cntmng?pid=bgi002:1965:37::129

Fick, S.E, \& Hijmans, R.J. (2017). Worldclim 2: New 1-km spatial resolution climate surfaces for global land areas. International Journal of Climatology, 37, (12), 43024315. https://doi.org/10.1002/joc.5086

Fosberg, F. R. (1961). A classification of vegetation for general purposes. Tropical Ecology, 2, $73-120$

French, H., \& Schur, Y. (2010). The principles of cryostratigraphy. Earth-Science Review, (101), 190-206. https://doi.org/10.1016/j.earscirev.2010.04.002

Gaussen, H. (1955). Détermination des climats par la méthode des courbes ombrothermiques. Compte Rendus Hebdomadaires des Séances. Académie des Sciences, 240, 642-644.

Goldsmith F.B. (1974). An assessment of the Fosberg and Ellenberg methods of classifying vegetation for conservation purposes. Biological Conservation, 6(1), 36. https://doi.org/10.1016/0006-3207(74)90034-2

Grisebach A. (1838). Über den Einfluß des Klimas auf die Begrenzung der natürlichen Floren. Linnaea, (12), 159-200. 
Hijmans, R.J., Cameron S.E., Parra J.L., Jones P.G., \& Jarvis A. (2005). Very high resolution interpolated climate surfaces for global land areas. International Journal of Climatology, 25, 1965-1978. https://doi.org/10.1002/joc.1276

Holdridge, L. R. (1947). Determination of world plant formation from simple climatic data. Science, 105, 267-268. https://doi.org/10.1126/science. 105.2727.367

Holdridge, L.R. (1967). Life zone ecology. Tropical Science Center. San José de Costa Rica. Retrieved from http://reddcr.go.cr/sites/default/files/centro-dedocumentacion/holdridge_1966__life_zone_ecology.pdf

Huguet del Villar, E. (1929). Geobotánica. Barcelona, Labor.

Hutchinson M.F. (2004). Anusplin Version 4.3. Centre for Resource and environmental Studies. The Australian National University. Canberra, Australia. Retrieved from https://fennerschool.anu.edu.au/research/products/anusplin

Kerner, von M. A. (1895). The Natural History of Plants (English tr. by F. W. Oliver). London. Retrieved from

https://ia800207.us.archive.org/4/items/naturalhistory01kern/naturalhistory01kern.pdf

Köppen W. (1936). Das Geographische System der Klima. In W. Kooppen \& R. Geiger (Eds.), Handbuch der Klimatologie. V.1 Gebr Bomtraeger. Berlin. Retrieved from http://koeppengeiger.vu-wien.ac.at/pdf/Koppen_1936.pdf

Köppen, W. (1918). Klassification der Klimate nach Temperatur, Niederschlag und Jahreslauf. Petermanns Geographische Mitteilungen, (64), 193-203, 243-248. Retrieved from http://koeppen-geiger.vu-wien.ac.at/pdf/Koppen_1918.pdf

Mather J., \& Yoshioka G. (1966). The role of climate in the distribution of vegetation. In D. Carter, \& J. Mather (1966). Climate Classification for Environmental Biology. Elmer. New Jersey, https://doi.org/10.1111/j.1467-8306.1968.tb01634.x

Medina, E. (1977). Introducción a la ecofisiología vegetal. Secretaría General de la OEA. Washington D.C. Retrieved from

https://www.academia.edu/18070597/Monograf\%C3\%ADa_16._Introducci\%C3\%B3n_a_la_ec ofisiolog\%C3\%ADa_vegetal?auto=download

Meyer, B.S., Anderson, D. B., \& Bohning, R. H. (1966). Introducción a la fisiología vegetal. Buenos Aires, EUDEBA 
Miller, A. (1951). Three New Climatic Maps. Transactions and Papers (Institute of British Geographers), (17), 15-20.

Montero de Burgos, J.L., \& García Salmerón, J. (1981). Atmósfera, I. El Clima. In Tratado de Medio Ambiente, Tomo II. Madrid, Universidad Politécnica de Madrid, CEOTMA, INTA, ICONA. Montero de Burgos, J.L., \& González, J.L. (1974): Diagramas bioclimáticos. Madrid, ICONA, Spanish Ministry of Agriculture.

Olson, D. M., Dinerstein, E., Wikramanayake, E. D., Burgess, N. D., Powell, G. V. N., Underwood, E. C., ... Kassem, K. R. (2001). Terrestrial ecoregions of the world: a new map of life on Earth. Bioscience 51(11), 933-938. https://doi.org/10.1641/00063568(2001)051[0933:TEOTWA]2.0.CO;2

Paladini, B. (2016). Deforestación de la Mata Atlántica enn el litoral del Estado de Paraíba (Brasil). Cambios ambientales y riesgos geomorfológicods: voçorocas (Doctoral dissertation, University of Seville, Spain). Retrieved from https://idus.us.es/xmlui/handle/11441/38301

Porto de Lima, V.R. (2012). Caracterización biogeográfica del bioma de Caatinga en el sector semiárido de la cuenca del río Paraiba, Noreste de Brasil: propuesta de ordenación y gestión de un medio semiárido tropical (Doctoral dissertation, University of Seville, Spain). Retrieved from https://idus.us.es/xmlui/handle/11441/24222

Prentice C. (1990). Bioclimatic distribution of vegetation for general circulation models. Journal of Geophysical Research 95: 811-830. https://doi.org/10.1029/JD095iD08p11811

Schimper, A. F. W. (1903). Plant-geography upon a physiological basis. Revised and edited by Percy Bayley Balfour. Oxford Clarendon Press. Retrieved from https://archive.org/details/plantgeographyup00schi/page/n6

Thornthwaite C. (1933). The climates of the earth. Geographical Review, 23, 433440. https://doi.org/10.2307/209629

Thornthwaite C. (1948) An approach toward a rational classification of the climate. Geographical Review, 38, 55-89. https://doi.org/10.2307/210739

Thornthwaite, C. W., \& Mather, J. R. (1955). The Water Balance. Drexel Institute of Technology. Laboratory of Climatology. Publication in Climatology, 8, 1-104. 
Thornthwaite, C. W., \& Mather, J. R., \& Carter D.B. (1957): Instructions and Tables for Computing Potential Evapotranspiration and the Water Balance. Drexel Institute of Technology, Laboratory of Climatology. Publication in Climatology, (10), 181-311.

Thornton P.E., Running S.W., \& White M.A. (1997). Generating surfaces of daily meteorology variables over large regions of complex terrain. Journal of Hydrology, (190), 214251. https://doi.org/10.1016/S0022-1694(96)03128-9

Touchette B.W., \& Burkholder J.M. (2000). Overview of the physiological ecology of carbon metabolism in seagrasses. Journal of Experimental Marine Biology and Ecology, 250(1-2), 169205. https://doi.org/10.1016/s0022-0981(00)00196-9

Tricart J., \& Cailleux A. (1974). Le modele des región chaudes. Forests et savanes. Paris, Sedes. Traité de géomorphologie tome $\vee$.

Tuhkanen, S. (1980). Climatic parameters and indices in plant geography. Acta Phytogeographica Suecica, 67, 1-108. Retrieved from http://uu.divaportal.org/smash/get/diva2:565410/FULLTEXT01.pdf

Walter, H. (1997). Zonas de Vegetación y clima. Barcelona, Omega (Translated into Spanish by M. Costa from Eugen Ulmer, Stutgart, 1977).

Walter, H., \& Lieth, H. (1967). Klimadiagramm-Weltatlas. G. Fischer, Jena

Warming, E. (1909). Oecology of plants. An Introduction to the Study of Plant Communities. Oxford University Press. London. https://doi.org/10.5962/bhl.title.24132

Whittaker R.H. (1962). Classification of Natural Communities, Botanical Review, 28(1), 1239. http://dx.doi.org/10.1007/BF02860872

Whittaker R.H. (1975). Communities and Ecosystems. New York, Mac Millan Publishing. 


\section{Appendix A}

Listed below are the ArcGis algorithms to gather the rasters that enable us to obtain the maps of the 27 bioclimatic regimes.

a) Obtaining the monthly rasters for PET and OI

To obtain these, we began with the databases' coverage of average monthly temperatures, monthly precipitation, and the monthly $L$ value $\left(L_{i}\right)$ for latitudinal correction of monthly sunshine (Dune and Leopold, 1978): $\mathrm{L}_{i}=\left(\mathrm{Nd}_{i} / 30\right)-\left(\mathrm{N}_{\mathrm{i}} / 12\right)$, where $\mathrm{Nd}_{i}$ is the number of days of the month and $\mathrm{N}_{i}$ the astronomical duration of the day in hours of sun.

To obtain the value of PETmc (Thornthwaite's corrected monthly annual potential evapotranspiration): $P E T_{m c}=P E T_{m}{ }^{*} L_{m}, L m$ being the monthly correction value of the PET of Thornthwaite (Dunne and Leopold, 1978, Thornthwaite et al., 1957) where the monthly potential evapotranspiration is $\mathrm{PET}_{\mathrm{m}}=16^{*}\left(10 \mathrm{Tm} / \mathrm{I}_{\dagger}\right)^{a} ; \mathrm{Tm}$ monthly average temperature; $\mathrm{I}_{\dagger}$ annual heat index which is the sum of the monthly I value $\mathrm{It}=\mathrm{IIm}$; a: exponential parameter based on $I_{\uparrow}$ such as $a=\left.0.0000006751 *\right|_{\dagger} ^{3}-\left.0.000071^{*}\right|_{\dagger} ^{2}+\left.0.01792 *\right|_{\dagger}+0.49239$. Finally, Thornthwaite's Ombrothermic Index used is OI = 100 (P-PET)/PET. The algorithms for calculating Thornthwaite's ombrothermic index are shown in table A.1.

Table A. 1. ArcGis calculation algorithms for obtaining potential evapotranspiration and Thornthwaite's Ombrothermic Index

\begin{tabular}{|c|c|c|}
\hline VARIABLE & SYMBOL & $\begin{array}{c}\text { CALCULATION } \\
\text { ALGORITHM }\end{array}$ \\
\hline Monthly paralysis of plant activity due to temperature & VPTD $_{m}$ & Con("T $_{m}$ " $\left.<7.5,1,0\right)$ \\
\hline Annual paralysis of plant activity due to temperature & VPTD & $\Sigma$ "VPTD ${ }^{\prime \prime}$ \\
\hline Monthly paralysis of plant activity due to water & VPWD & $\begin{array}{c}\text { Con ("P }_{m} \text { " }-0.2 \text { * } \\
\text { "PET }\end{array}$ \\
\hline Annual paralysis of plant activity due to water & VPWD & $\Sigma$ "VPWD \\
\hline
\end{tabular}

Source: own elaboration 
b) Obtaining the monthly and annual rasters for paralysis of plant activity due to water deficit (VPWD) and thermal deficit (VPTD)

To calculate the paralysis of plant activity due to temperature, the raster is obtained for each month $\left(V P T D_{m}\right)$ that the monthly average temperature is lower than $7.5^{\circ}$. The annual VPTD is found using the sum of the monthly VPTD $m$.

Likewise, to calculate the plant paralysis due to water, the raster is obtained for each month $\left(V P W D_{m}\right)$ for which the following condition is met: VPWD $m=\left(P m-0.2 * P E T_{m}\right)$. The annual VPWD is found (table A.2) using the sum of the monthly VPWDm.

Table A.2. ArcGis calculation algorithms to obtain paralysis of plant activity due to temperature and water according to Montero de Burgos and González (1974)

\begin{tabular}{|c|c|c|}
\hline VARIABLE & SYMBOL & CALCULATION ALGORITHM \\
\hline Monthly evapotranspiration & $\mathrm{PET}_{\mathrm{m}}$ & $" \mathrm{~L}_{\mathrm{m}} "$ * 16 *Power $\left(10 * " \mathrm{t}_{\mathrm{m}} " /{ }^{\prime \prime} \mid \mathrm{t}^{\prime \prime}, " \mathrm{a} "\right)$ \\
\hline Monthly heat index & $I_{m}$ & Power ("T $\left.\mathrm{m}^{\prime \prime} / 5,1.514\right)$ \\
\hline $\begin{array}{c}\text { Exponential parameter } \\
\text { based on } I_{\dagger}\end{array}$ & a & $\begin{array}{l}\text { Power }\left(" I_{-} T^{\prime \prime}, 3\right) * 0.0000006751-\operatorname{Power}\left("{ }^{\prime \prime} I^{\prime \prime}, 2\right) \\
\quad * 0.000071+" I_{-}{ }^{\prime \prime} * 0.01792+0.49239\end{array}$ \\
\hline $\begin{array}{l}\text { Thornthwaite's } \\
\text { Ombrothermic Index }\end{array}$ & $\mathrm{l}_{0}$ & $100 *\left({ }^{\prime \prime} \mathrm{P}^{\prime \prime}-" \mathrm{PET}\right.$ ")/"PET" \\
\hline
\end{tabular}

Source: own elaboration

c) Obtaining the rasters for variables of conditional maps for tropicality, subtropicality and cold zones

To obtain the tropical mask, we obtained the following:

- The rasters that meet the condition that the monthly temperature is greater than $180 \mathrm{C}$. $\mathrm{T} 18 \mathrm{~m}$

- The sum of these monthly rasters T18=पT18m

- That the condition that raster T18 is equal to 12 is met

To obtain the mask for the cold zone, we obtained the raster that meets the condition that the annual paralysis of plant activity due to temperature is equal to or greater than 1 .

The subtropical mask is obtained using the dual condition that all the monthly average temperatures are greater than $7.5^{\circ} \mathrm{C}$ and at least some of them are lower than $18^{\circ} \mathrm{C}$ (Ttable A.3) 
Table A.3. ArcGis calculation algorithms to obtain paralysis of plant activity due to temperature and water according to Montero de Burgos and González (1974)

\begin{tabular}{|c|c|c|}
\hline VARIABLE & SYMBOL & $\begin{array}{c}\text { CALCULATION } \\
\text { ALGORITHM }\end{array}$ \\
\hline $\begin{array}{c}\text { Months with average monthly temperature } \\
\text { greater than } 18^{\circ} \mathrm{C}\end{array}$ & $\mathrm{T} 18_{\mathrm{m}}$ & Con $^{\prime \prime} \mathrm{T}_{\mathrm{m}}$ " $\left.>=18,1,0\right)$ \\
\hline $\begin{array}{c}\text { Sum of months with average monthly temperature } \\
\text { greater than } 18^{\circ} \mathrm{C}\end{array}$ & $\mathrm{T} 18$ & $\Sigma \mathrm{T} 18_{\mathrm{m}}$ \\
\hline $\begin{array}{c}\text { Tropical zone mask } \\
\text { Cold zone mask }\end{array}$ & trop & Con("T18" $==12,1,0)$ \\
\hline Cold & Con("VPTD" $>=1,1,0)$ \\
\hline
\end{tabular}

Source: own elaboration 
d) Obtaining rasters for bioclimatic regimes

Table A.4. ArcGis algorithms for obtaining the bioclimatic regimes

\begin{tabular}{|c|c|c|c|}
\hline \multicolumn{2}{|c|}{ ZONE } & REGIME & CALCULATION ALGORITHM \\
\hline \multirow{7}{*}{\multicolumn{2}{|c|}{ TROPICAL }} & ombrophyllo & Con("trop" $==1$, Con("VPWD" $<1$, Con ("P" >= 2000,1,0)) \\
\hline & & mesophyllo & Con("trop" == 1, Con("VPWD" $<1$, Con("P" $<2000,2,0)))$ \\
\hline & & tropophyllo & $\begin{array}{l}\text { Con("trop" }==1, \text { Con("VPWD " }>=1 \text {, Con("VPWD" }<= \\
4, \operatorname{Con}(" P ">2000,3,0))) \text { ) }\end{array}$ \\
\hline & & xerophyllo & $\begin{array}{l}\text { Con("trop" }==1 \text {, Con("VPWD" }>4 \text {, Con("VPWD" }<=8 \text {, Con("P" } \\
<2000,4,0)()) \text { ) }\end{array}$ \\
\hline & & hiperxerophyllo & Con $(" \operatorname{trop} "==1$, Con $(" V P W D ">8,5,0))$ \\
\hline & & ombro tropophyllo & $\begin{array}{l}\text { Con("trop" }==1, \operatorname{Con}(" V P W D ">=1, \text { Con }(" V P W D "<= \\
\left.\left.\left.4, \operatorname{Con}\left(" P^{\prime \prime}>=2000,6,0\right)\right)\right)\right)\end{array}$ \\
\hline & & ombro xerophyllo & Con("trop" $\left.==1, \operatorname{Con}\left(" \bigvee P W D ">4, \operatorname{Con}\left(" P^{\prime \prime}>=2000,7,0\right)\right)\right)$ \\
\hline \multirow{5}{*}{\multicolumn{2}{|c|}{ SUBTROPICAL }} & euritermo ombrophyllo & Con("subtrop" $==1$, Con("VPWD" $<1$, Con $\left.\left.\left(" \mathrm{P}^{\prime \prime}>=2000,8,0\right)\right)\right)$ \\
\hline & & euritermo mesophyllo & Con("subtrop" ==1, Con("VPWD" $<1$, Con("P" $<2000,9,0)$ )) \\
\hline & & euritermo tropophyllo & $\begin{array}{l}\text { Con("subtrop" }==1 \text {,Con("VPWD" }>=1 \text {,Con("VPWD" }<= \\
4,10,0)) \text { ) }\end{array}$ \\
\hline & & euritermo xerophyllo & Con("subtrop" $==1$,Con("VPWD" $>4$, Con("VPWD" $<=8,11,0))$ ) \\
\hline & & euritermo hiperxerophyllo & Con ("subtrop" $==1$, Con ("VPWD" $>8,12,0))$ \\
\hline \multirow[t]{15}{*}{ COLD } & \multirow[t]{5}{*}{ CRYO } & cryo ombrophyllo & $\begin{array}{l}\text { Con("VPTD" }>0 \text {, Con("VPTD" }<=5 \text {, Con("VPWD" }<1 \text {, Con("P" } \\
>=2000,13,0))))\end{array}$ \\
\hline & & cryo mesophyllo & $\begin{array}{l}\text { Con("VPTD" }>0 \text {, Con("VPTD" }<=5 \text {, Con("VPWD" }<1 \text {, Con("P" }< \\
2000,14,0))) \text { ) }\end{array}$ \\
\hline & & cryo tropophyllo & $\begin{array}{l}\text { Con("VPTD" }>0, \text { Con("VPTD" }<=5 \text {, Con("VPWD" }>=1 \text {, } \\
\text { Con("VPWD" }<=4,15,0))) \text { ) }\end{array}$ \\
\hline & & cryo xerophyllo & $\begin{array}{l}\text { Con("VPTD" }>0, \text { Con("VPTD" }<=5 \text {, Con("VPWD" }>4, \\
\text { Con("VPWD" }<=8,16,0))) \text { ) }\end{array}$ \\
\hline & & cryo hiperxerophyllo & Con("VPTD" $>0$, Con("VPTD" $<=5$, Con("VPWD" $>8,17,0)))$ \\
\hline & \multirow[t]{5}{*}{ MESOCRYO } & mesocryo ombrophyllo & $\begin{array}{l}\text { Con("VPTD" }>5 \text {, Con("VPTD" }<=9 \text {, Con("VPWD" }<1 \text {, Con("P" } \\
>=2000,18,0))) \text { ) }\end{array}$ \\
\hline & & mesocryo mesophyllo & $\begin{array}{l}\text { Con("VPTD" }>5 \text {, Con("VPTD" }<=9 \text {, Con("VPWD" }<1 \text {, Con }\left(" P^{\prime \prime}<\right. \\
2000,19,0) 1))\end{array}$ \\
\hline & & mesocryo tropophyllo & 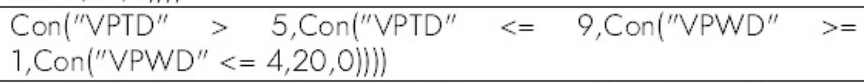 \\
\hline & & mesocryo xerophyllo & $\begin{array}{l}\text { Con("VPTD" }>\quad 5, \operatorname{Con}\left(" V P T D^{\prime \prime} \quad<=\text { 9,Con("VPWD" }>\right. \\
4, \operatorname{Con}(" V P W D "<=8,21,0)))\end{array}$ \\
\hline & & mesocryo hiperxerophyllo & Con("VPTD" > 5, Con("VPTD" $<=9$, Con("VPWD" > 8, 22,0)) \\
\hline & \multirow[t]{5}{*}{ HIPERCRYO } & hipercryo ombrophyllo & Con("VPTD" > 9, Con("VPWD" < 1, Con("P" >= 2000,23,0)) \\
\hline & & hipercryo mesophyllo & Con("VPTD" $>$ 9, Con("VPWD" < 1, Con("P" < 2000,24,0)) \\
\hline & & hipercryo tropophyllo & Con("VPTD" $>9$, Con("VPWD" $>=1$, Con("VPWD" $<=4,25,0)))$ \\
\hline & & hipercryo xerophyllo & Con("VPTD" > 9, Con("VPWD" > 4,Con("VPWD" $<=8,26,0)))$ \\
\hline & & hipercryo hiperxerophyllo & Con("VPTD" $>9$, Con("VPWD" $>8,27,0))$ \\
\hline
\end{tabular}

Source: own elaboration 